ISSN: 2302-8556

E-Jurnal Akuntansi

Vol.28.1.Juli (2019): 322-350

DOI: https://doi.org/10.24843/EJA.2019.v28.i01.p13

\title{
Pengaruh Audit Operasional dan Pengendalian Internal Terhadap Kinerja Karyawan
}

\author{
Ida Ayu Dewi Prayogi Manuaba ${ }^{1}$ \\ Ketut Muliartha $\mathbf{R M}^{2}$
}

\author{
${ }^{1,2}$ Fakultas Ekonomi dan Bisnis Universitas Udayana (Unud), Bali, Indonesia \\ e-mail: dewiprayogimanuaba88@gmail.com
}

\begin{abstract}
ABSTRAK
Tujuan penelitian ini untuk mengetahui pengaruh audit operasional dan pengendalian internal terhadap kinerja karyawan. Penelitian ini dilakukan pada perusahaan jasa perhotelan Ayodya Resort Bali. Pengumpulan data dilakukan melalui wawancara dan kuesioner dengan sampel 40 responden yang merupakan auditee dari departemen accounting, departemen human resource, departemen sales and marketing, departemen engineering, departemen front office, departemen food and beverage, departemen housekeeping, dan departemen security. Teknik analisis data yang digunakan adalah analisis regresi linier berganda. Berdasarkan hasil penelitian menunjukkan bahwa audit operasional dan pengendalian internal berpengaruh positif terhadap kinerja karyawan pada hotel Ayodya Resort Bali.

Kata kunci: Audit operasional, pengendalian internal, kinerja karyawan.
\end{abstract}

\begin{abstract}
The research objective is to determine the effect of operational audits and internal controls on employee performance. This research was conducted at the hospitality service company Ayodya Resort Bali. Data collection was conducted through interviews and questionnaires with a sample of 40 respondents who were auditees from the accounting department, human resource department, sales and marketing department, engineering department, front office department, food and beverage department, housekeeping department, and security department. The data analysis technique used is multiple linear regression analysis. Based on the result of the study indicate that operational audits and internal control have a positive effect on employee performance at the Ayodya Resort Bali hotel.
\end{abstract}

Keywords: Operational audit, internal control, employee performance.

\section{PENDAHULUAN}

Perkembangan dunia bisnis saat ini yang semakin pesat menuntut suatu perusahaan untuk secara efektif dan efisien dalam mengelola usahanya sehingga tercipta suatu keunggulan kompetitif. Diperlukan adanya suatu sistem pengawasan yang baik di dalam sebuah perusahaan. Pertumbuhan ekonomi dan dunia bisnis yang mulai 
menampakkan hasil positif sekarang ini haruslah dihadapi dengan kesiapan untuk perubahan dan keberhasilan dalam proses perubahan itu sendiri menuntut kemampuan dalam mengadopsi nilai-nilai pengetahuan dan praktek-praktek bisnis baru yang berporos pada good corporate governance. Kotabe dan Kothari (2016) menyatakan perusahaan harus mampu meningkatkan kemampuan bersaing dengan terus-menerus memperbaiki kegiatan operasional agar tetap dapat bertahan.

Pesatnya perkembangan dunia bisnis menuntut suatu perusahaan untuk beradaptasi dengan perubahan lingkungan yang makin kompetitif dan melakukan peningkatan strategi bisnis agar tetap dapat bersaing untuk meraih tujuan usahanya. Perkembangan teknologi, fluktuasi ekonomi dan kondisi dinamis merupakan hal yang harus dihadapi oleh perusahaan. Perusahaan diharuskan memiliki keterampilan dan kompetensi dalam menjalankan suatu usaha bisnis, baik dalam lingkungan internal maupun lingkungan eksternal. Adanya tantangan tersebut, menuntut perusahaan untuk memiliki sikap yang bijak saat mengambil sebuah keputusan dan mampu mengkoordinasi bagian-bagian yang terkait untuk menjalankan aktivitas perusahaan (Hidayati, 2013).

Perusahaan yang dikendalikan dengan efektif terletak pada sikap manajemen, semakin berkembangnya suatu perusahaan menuntut pula perkembangan di bidang pemeriksaan. Pemeriksaan yang dilakukan tidak hanya pemeriksaan keuangan saja tetapi juga pemeriksaan yang menekankan penilaian sistematis dan objektif serta berorientasi pada tujuan untuk memperoleh keyakinan tentang keefektifan dan memberi pendapat atas kewajaran laporan keuangan yang diperiksa. Pimpinan 
perusahaan memerlukan audit operasional yang menyajikan informasi mengenai aktivitas operasional perusahaan. Audit operasional disebut juga operasional audit, audit fungsional, audit sistem, adalah suatu pemeriksaan terhadap kegiatan operasi perusahaan, termasuk kebijakan akuntansi dan kebijakan operasional yang telah di tentukan manajemen, untuk mengetahui apakah kegiatan operasi tersebut sudah dilakukan secara efektif, efisien, dan ekonomis (Septianingrum, 2017). Arvianita (2015) menyatakan praktik audit operasional dapat dilakukan oleh auditor internal perusahaan tetapi tidak menutup kemungkinan auditor eksternal melakukan audit tersebut. Dengan demikian, audit operasional dapat digunakan untuk menilai kinerja apakah kegiatan operasional perusahaan telah dilakukan sesuai dengan prosedur yang ada.

Perangin-angin (2017) menyatakan dalam menjalankan kegiatan operasional perusahaan tentunya juga harus didukung dengan adanya sumber daya manusia atau karyawan yang berkualitas untuk mendukung tercapainya tujuan utama perusahaan, karyawan adalah bagian yang sangat penting dalam sebuah perusahaan, keterlibatan karyawan dalam perusahaan dimulai dari awal berdirinya perusahaan, yaitu menyusun dan merencanakan tujuan perusahaan yang akan dicapai baik untuk jangka pendek maupun jangka panjang sampai perusahaan tersebut menjalankan kegiatan operasional perusahaan dan mengendalikannya sampai kepada tercapainya tujuan perusahaan tersebut. Kramer dan Rinsum (2016) menyatakan perusahaan dalam mencapai tujuannya, manajemen perusahaan akan memeriksa kinerja karyawannya apakah sudah sesuai atau tidak dengan standar operasional perusahaan yang berlaku. 
Sari (2014) menyatakan dalam melaksanakan kegiatan operasinya, manajemen perusahaan tidak dapat mengasumsikan bahwa segala sesuatu telah mereka lakukan dengan benar. Kenyataannya, manajemen perusahaan akan menghadapi kesalahan. Tampang (2011) menyatakan fungsi pengawasan dan pengendalian manajemen, menimbulkan aktivitas audit (pemeriksaan). Secara lebih luas audit juga dibutuhkan dalam menilai pertanggung jawaban manajemen kepada berbagai pihak yang berkepentingan di dalam perusahaan. Dari hasil audit dapat diketahui apakah laporan yang diberikan oleh manajemen sesuai dengan kenyataan yang sebenarnya terjadi atau apakah operasi yang berjalan sesuai dengan ketentuan, peraturan, dan kebijakan yang telah ditetapkan perusahaan. Al-khaddash dan Ramadan (2013) menyatakan audit memainkan peran penting dalam mengembangkan dan meningkatkan ekonomi global dan perusahaan bisnis.

Pengendalian internal juga merupakan hal yang penting dalam kegiatan operasional yang dijalankan oleh perusahaan, pengendalian internal dapat meningkatkan ketelitian dan kepercayaan data informasi akuntansi dengan mencegah adanya kesalahan (Yadnyana dan Dewi, 2015). Sistem pengendalian internal sangat penting bagi setiap organisasi, oleh karena itu diperlukan kemampuan manajemen untuk menjaga kekayaan organisasi, mengecek ketelitian data akuntansi, dan mendorong dipatuhinya kebijakan manajemen yang merupakan tujuan dari sistem pengendalian internal (Mulihartini, 2016).

Penilaian pengendalian internal yang akurat dari entitas bisnis telah dipertanyakan baru-baru ini. Ada kekhawatiran bahwa penilaian pengendalian internal dan 
pengendalian operasional yang juga dapat mempengaruhi kualitas pelaporan keuangan, dan masalah ini sebagian besar telah diabaikan oleh penelitian sebelumnya (Ji dan Qu, 2018). Pengendalian itu dapat berupa kebijakan, prosedur, alat-alat, dan tindakan untuk mencegah secara dini tindakan yang akan menyimpang dari jalur pencapaian tujuan organisasi, lembaga, atau perusahaan. Pengendalian internal terdiri atas rencana organisasi dan keseluruhan metode atau cara serta ukuran yang dikoordinasikan dengan tujuan untuk mengamankan harta kekayaan, meneliti keakuratan, dapat dipercayanya data akuntansi, meningkatkan efisiensi operasi, dan mendorong dipatuhinya kebijakan manajemen yang telah ditetapkan (Yayasan Pendidikan Internal Audit, 2008:4) dalam (Aprilia dan Zultilisna, 2017).

Shu dan Chen (2018) menyatakan pengendalian internal adalah proses yang dapat diimplementasikan oleh dewan entitas, manajemen, dan karyawan dalam entitas tersebut. Faktor kompleksitas perusahaan, kondisi keuangan, tingkat pertumbuhan, dan audit internal semuanya terkait dengan kualitas pengendalian internal. Karakteristik dewan direksi dan komite auditnya (seperti dewan pengawas, independensi, dan profesionalisme komite audit, atau kemampuan professional chief financial officer) semuanya terkait dengan kualitas pengendalian internal. McNulty dan Akhigbe (2017) menyatakan dalam sebuah perusahaan pengendalian internal berfungsi untuk mengendalikan seluruh kegiatan perusahaan.

Arvianita (2015) menyatakan tujuan dari adanya pengendalian internal perusahaan adalah untuk menilai tingkat keefektivitasan dan efisiensi seluruh kegiatan apakah sudah sesuai dengan tujuan. Jika pengendalian internal dalam suatu 
perusahaan tersebut lemah, maka kemungkinan terjadinya kesalahan yang menyebabkan efektivitas kinerja menjadi lemah juga. Mulihartini (2016) menyatakan kualitas sistem pengendalian internal pada setiap organisasi dipengaruhi oleh kualitas sumber daya manusia yaitu orang yang bekerja pada suatu organisasi yang disebut pegawai, karyawan, tenaga kerja, dan lain sebagainya. Sumber daya manusia dikatakan berkualitas apabila wewenang dan tanggung jawab yang diberikan kepada mereka mampu dilaksanakan dengan baik.

Bali dan pariwisata tidak bisa dipisahkan, keindahan alam dan keunikan serta keragaman budayanya menjadi daya tarik utama bagi para wisatawan baik lokal maupun internasional. Perkembangan sektor pariwisata di Bali memberikan dampakpositif dalam hal menciptakan lapangan pekerjaan yang baru, meningkatkan pendapatan devisa negara, serta memperkenalkan keragaman budaya sebagai salah satu identitas Indonesia di mata dunia. Pulau Bali merupakan daerah tujuan wisata yang sangat populer, para investor telah melihat peluang ini sebagai suatu kesempatan untuk mengembangkan bisnis mereka dengan membangun hotel-hotel yang berbintang, resort, dan juga motel.Yadnyana (2009) menyatakan melalui sektor pariwisata diharapkan dapat memperluas kesempatan berusaha dan memperluas lapangan kerja yang tersedia. Sektor pariwisata ini dapat menekan atau memperkecil tingkat pengangguran sebagai akibat tenaga kerja yang tersedia. 
Hight dan Okumus (2018) menyatakan perhotelan dituntut untuk menjadi organisasi jasa yang berfokus pada konsumen sehingga memiliki kemampuan untuk dapat mempertahankan kelangsungan usahanya. Aprilia dan Zutilisna (2017) menyatakan setiap hotel dituntut untuk menciptakan pelayanan yang baik, untuk menciptakan hal tersebut diperlukan serangkaian kegiatan pemeriksaan dan evaluasi atas kegiatan operasional yang dilakukan oleh hotel, berupa audit operasional. Hasil audit operasional tersebut dapat digunakan untuk bahan perbaikan ke depan sehingga hotel dapat memberikan pelayanan yang efektif dan efisien.

Ayodya Resort Bali adalah salah satu hotel yang berada dikawasan destinasi pariwisata ITDC (Indonesian Tourism Development Corporation) Nusa Dua, Bali. Ayodya Resort Bali telah menerapkan audit operasional yang dilakukan oleh auditor internal dari hotel. Berdasarkan wawancara yang diperoleh dari Director of Finance AyodyaResort Bali menyatakan audit operasional terhadap penilaian kinerja dilaksanakan setiap tahunnya yaitu sekali dalam setahun. Selain pelaksanaan audit, Ayodya Resort Bali juga memiliki sistem pengendalian internal yang dijalankan oleh bagian Income pada departemen Accounting sebagai Satuan Pengawas Internal (SPI) pada hotel dan mengawasi seluruh departemen pada hotel yang berhubungan dengan revenue hotel.

Fenomena yang terjadi berdasarkan wawancara yang diperoleh dari Director of Finance pada Ayodya Resort Bali ditemukan rekomendasi hasil audit yang masih belum ditindak lanjuti pada bagian yang memiliki peranan penting bagi terciptanya kualitas pelayanan yang baik bagi konsumen seperti pada bagian operasi dan 
pemasaran rekomendasi hasil audit yang belum ditindak lanjuti yaitu belum maksimalnya target pemasaran ke wisatawan eropa. Penurunan kinerja perusahaan ini tercermin dari penurunan kinerja karyawan pada bagian marketing pada periode September s/d Desember 2017. Bagian organisasi dan sumber daya manusia rekomendasi hasil audit yang belum ditindak lanjuti yaitu masih kurangnya perekrutan karyawan yang bisa berbahasa cina dan perlu meningkatkan pelatihan karyawan bahasa cina dan pelatihan karyawan terkait keselamatan kerja. Bagian food and beverage rekomendasi hasil audit yang belum ditindak lanjuti yaitu sedikitnya karyawan yang melayani tamu yang bisa berbahasa cina.

Fenomena tersebut merupakan faktor yang mendukung penulis untuk melakukan penelitian pada bidang audit operasional dan pengendalian internal di Hotel Ayodya Resort Bali.

Berdasarkan uraian latar belakang di atas, adapun rumusan masalah dalam penelitian ini adalah 1) Apakah audit operasional berpengaruh terhadap kinerja karyawan? 2) Apakah pengendalian internal berpengaruh terhadap kinerja karyawan?

Martini (2017) mengemukakan bahwa Theory of Planned Behavior telah muncul sebagai salah satu dari kerangka kerja yang paling berpengaruh dan konsep yang populer pada penelitian di bidang kemanusiaan. Bagian-bagian di dalam TPB seperti sikap, norma subjektif, dan persepsi kontrol keperilakuan ditentukan melalui keyakinan-keyakinan utama. Determinan suatu perilaku merupakan hasil dari penilaian keyakinan - keyakinan dari individu, baik sebagai secara positif maupun negatif. Dewberry dan Jackson (2018) menyatakan keyakinan - keyakinan perilaku 
membentuk suatu sikap menyukai terhadap perilaku, keyakinan normatif menghasilkan tekanan sosial atau norma subjektif, dan keyakinan kontrol akan memberikan persepsi kontrol keperilakuan. Bersama-sama sikap terhadap perilaku, norma subjektif, dan persepsi kontrol keperilakuan akan menimbulkan niat perilaku (behavioral intention) dan selanjutnya terbentuk perilaku (behavior).

Keyakinan positif yang dimiliki oleh seorang karyawan akan menimbulkan niat yang tinggi untuk meningkatkan kinerjanya. Berdasarkan keyakinan tersebut akan mempengaruhi perilaku seseorang termasuk perilaku dalam bekerja. Kinerja merupakan hasil dari proses bekerja secara kualitas maupun kuantitas yang dicapai oleh karyawan dalam pelaksanaan tugas pekerjaan sesuai dengan tanggung jawab yang diberikan, dan faktor-faktor yang berpengaruh yaitu faktor individu, faktor psikologis serta faktor organisasi (Martini, 2017). Faktor organisasi yang mempengaruhi sikap dan perilaku karyawan yang akan diteliti pada penelitian ini terkait dengan penerapan audit operasional dan pengendalian internal yang diduga berpengaruh pada kinerja karyawan Ayodya Resort Bali.

Audit menurut Mulyadi (2010:9) dalam Iswara (2015) adalah suatu proses sistematik untuk memperoleh dan mengevaluasi bukti secara objektif mengenai pernyataan-pernyataan tentang kegiatan dan kejadian ekonomi, dengan tujuan untuk menetapkan tingkat kesesuaian antara pernyataan-pernyataan tersebut dengan kriteria yang telah ditetapkan, serta penyampaian hasil-hasilnya kepada pemakai yang berkepentingan. 
Agoes (2014:4) menyatakan bahwa audit merupakan suatu pemeriksaan yang dilakukan secara sistematis dan kritis, oleh pihak yang independen, terhadap informasi yang diberikan oleh manajemen beserta bukti-buktinya dan catatan-catatan pembukuan, dengan tujuan untuk dapat memberikan pendapat mengenai kewajaran informasi tersebut.

Berdasarkan pengertian para ahli diatas dapat disimpulkan bahwa audit adalah proses sistematis yang dilakukan oleh seseorang yang kompeten dan independen untuk mendapatkan bukti-bukti dan mengevaluasi secara objektif mengenai pernyataan-pernyataan tentang kegiatan dan kejadian ekonomi untuk dapat menentukan dan melaporkan kesesuaian pernyataan tersebut dengan kriteria yang telah ditetapkan, kemudian menyampaikan hasilnya kepada pihak-pihak yang berkepentingan.

Audit operasional ataupun pengawasan intern merupakan suatu pemeriksaan terhadap kegiatan operasi suatu perusahaan, termasuk kebijakan akuntansi dan kebijakan operasional yang telah ditentukan oleh manajemen, untuk mengetahui apakah kegiatan operasi tersebut sudah dilakukan secara efektif, efisien, dan ekonomis. Pada umumnya definisi dari audit manajemen menekankan pada penilaian efektivitas, efisiensi dan ekonomisasi. Istilah audit manajemen sering digunakan bergantian dengan istilah audit operasional (Septianingrum, 2017).

Pengendalian internal menurut Committee of Sponsoring Organizations of the Treadway Commission (COSO) yang diadopsi oleh Institut Akuntan Publik Indonesia (IAPI) dalam Shintia dan Erawati (2017) mendefinisikan pengendalian internal 
sebagai suatu proses yang dijalankan oleh dewan komisaris, manajemen, dan personel lain entitas yang didesain untuk memberikan keyakinan memadai tentang pencapaian empat golongan tujuan berikut ini: 1) kehandalan pelaporan keuangan, 2) menjaga kekayaan dan catatan organisasi, 3) efektivitas dan efisiensi operasi, dan 4) kepatuhan terhadap hukum dan peraturan yang berlaku.

Kinerja karyawan didefinisikan sebagai gambaran hasil pencapaian dari pelaksanaan kegiatan untuk mewujudkan target yang telah ditetapkan oleh perusahaan melalui sebuah perencanaan strategi organisasi (Noviani, 2018). Iqbal dan Asrar-ul-Haq (2018) menyatakan kinerja karyawan berarti tindakan terkait tugas yang diharapkan dari seorang karyawan dan bagaimana tindakan itu dilakukan. Kinerja karyawan harus diingat untuk meningkatkan kompetisi perusahaan. Kinerja tergantung pada tingkat kesiapan karyawan yang tinggi atau rendah yang menggambarkan bahwa sikap karyawan terhadap perubahan kesiapan memiliki pengaruh besar karena karyawan yang berbeda memiliki tingkat pemahaman yang berbeda.

Penelitian terdahulu mengenai audit operasional telah dilakukan oleh Septianingrum (2017) yang menemukan audit manajemen berpengaruh positif terhadap kinerja karyawan. Audit manajemen yang dilakukan di Bank Panin Cabang Kendari telah dapat meningkatkan kinerja karyawan bank. Kinerja karyawan yang setiap periodenya dilakukan pemeriksaan untuk dapat dievaluasi kemudian diberikan solusi dan saran terhadap permasalahan yang ditemukan. Penelitian yang dilakukan oleh Arvianita (2015) menemukan audit operasional berpengaruh positif dan 
signifikan terhadap efektivitas pelayanan kesehatan di Rumah Sakit dengan diterapkannya audit operasional yang baik maka semakin meningkat pula efektivitas pelayanan kesehatan yang diberikan oleh Rumah Sakit. Penelitian yang dilakukan oleh Rahmawati (2017) menemukan audit operasional berpengaruh secara signifikan terhadap kinerja karyawan Rumah Sakit dr H Marzoeki Bogor. Berdasarkan uraian tersebut, maka hipotesis dalam penelitian ini sebagai berikut:

$\mathrm{H}_{1}$ : Audit operasional berpengaruh positif terhadap kinerja karyawan.

Penelitian terdahulu mengenai pengendalian internal telah dilakukan oleh Arvianita (2015) yang menemukan pengendalian internal berpengaruh positif dan signifikan terhadap efektivitas kinerja karyawan rumah sakit. Penelitian Mirnasari dan Suardhika (2018) menemukan pengendalian internal memberikan pengaruh positif terhadap kinerja karyawan pada Bank Perkreditan Rakyat di kota denpasar. Dengan adanya pengendalian internal dapat mengurangi kemungkinan kesalahan ataupun tindakan yang tidak sesuai dengan aturan yang dilakukan oleh karyawan. Penelitian Agus dan Putra (2018) menemukan pengendalian internal berpengaruh positif terhadap kinerja Pemerintah Daerah. Berdasarkan uraian tersebut, maka hipotesis dalam penelitian ini sebagai berikut:

$\mathrm{H}_{2}$ : Pengendalian internal berpengaruh positif terhadap kinerja karyawan. 


\section{METODE PENELITIAN}

Lokasi penelitian merupakan suatu tempat atau wilayah dimana penelitian dilakukan. Penelitian ini dilakukan pada perusahaan yang bergerak dalam bidang jasa penginapan hotel Ayodya Resort Bali, Nusa Dua, Badung, Bali, Indonesia.

Populasi yang ditentukan penulis adalah berasal dari delapan departemen yang ada di Ayodya Resort Bali yang berkaitan dengan judul penelitian yaitu; departemen accounting, departemen human resource, departemen sales and marketing, departemen engineering, departemen front office, departemen food and beverage, departemen housekeeping, dan departemen security serta auditor internal Ayodya Resort Bali yang keseluruhannya berjumlah 50 orang dan merupakan karyawan dari kalangan manajer level menengah (middle manager). Karena dalam penelitian ini jumlah populasinya telah diketahui, maka untuk menentukan jumlah sampel minimal penulis menggunakan Rumus Slovin untuk menghitungnya. Adapun Rumus Slovin adalah sebagai berikut:

$\mathrm{n}=\frac{\mathrm{N}}{1+\mathrm{NE}^{2}}$

Keterangan :

$\mathrm{n}=$ Jumlah sampel minimal

$\mathrm{N}=$ Jumlah populasi

$\mathrm{e}=$ Persentase kelonggaran ketelitian karena kesalahan pengambilan sampel 
Jumlah populasi yang diteliti pada Ayodya Resort Bali ada 50 orang. Jadi untuk populasi $(\mathrm{N})$ sebanyak 50 orang pada tingkat kesalahan pengambilan sampel (e) $10 \%$. Maka jumlah sampel yang dibutuhkan adalah :

$\mathrm{n}=\frac{50}{1+50(0,1)^{2}}=33,33=33$

Analisis regresi linier berganda digunakan untuk mengukur pengaruh antara lebih dari satu variabel bebas terhadap variabel terikat. Berdasarkan pembahasan teori, data penelitian, variabel-variabel penelitian, dan penelitian terdahulu maka bentuk persamaan regresi berganda penelitian ini menggunakan model sebagai berikut :

$\mathrm{Y}=\alpha+\beta_{1} \mathrm{X}_{1}+\beta_{2} \mathrm{X}_{2}+\varepsilon$

Keterangan :

$\alpha$

$\beta_{1}$ dan $\beta_{2}$

$\mathrm{X}_{1}$

$\mathrm{X}_{2}$

$\mathrm{Y}$

$\varepsilon$
: Konstanta

: Koefisien regresi

: Audit operasional

: Pengendalian internal

: Kinerja Karyawan

: Error Term

\section{HASIL DAN PEMBAHASAN}

Karakteristik responden merupakan profil dari keseluruhan responden yang berpartisipasi dalam mengisi kuesioner dalam penelitian ini. Secara garis besar karakteristik responden dilihat dari jenis kelamin, jabatan, lama bekerja, dan pendidikan terakhir. Karakteristik responden dapat dilihat pada Tabel 1 sebagai berikut. 
ISSN: 2302-8556

E-Jurnal Akuntansi

Vol.28.1.Juli (2019): 322-350

Tabel 1.

Karakteristik RespondenPenelitian

\begin{tabular}{|c|c|c|c|c|}
\hline \multirow{2}{*}{ No } & \multirow{2}{*}{ Karakteristik } & \multirow{2}{*}{ Keterangan } & \multicolumn{2}{|c|}{ Jumlah } \\
\hline & & & Orang & Persentase $(\%)$ \\
\hline \multirow{3}{*}{1} & \multirow{2}{*}{ JenisKelamin } & Laki-laki & 24 & $60 \%$ \\
\hline & & Perempuan & 16 & $40 \%$ \\
\hline & \multicolumn{2}{|c|}{ Total } & 40 & $100 \%$ \\
\hline \multirow{4}{*}{2} & \multirow{4}{*}{ Lama Bekerja } & $1-10$ tahun & 6 & $15 \%$ \\
\hline & & $11-20$ tahun & 6 & $15 \%$ \\
\hline & & $>20$ & 28 & $70 \%$ \\
\hline & & & 40 & $100 \%$ \\
\hline \multirow{9}{*}{3} & \multirow{9}{*}{ Jabatan } & Accounting & 11 & $28 \%$ \\
\hline & & Engineering & 4 & \multirow[t]{2}{*}{$10 \%$} \\
\hline & & Food \& Beverage & 3 & \\
\hline & & Front Office & 5 & $13 \%$ \\
\hline & & Housekeeping & 7 & \multirow{2}{*}{$10 \%$} \\
\hline & & Human Resources & 4 & \\
\hline & & Sales \& Marketing & 4 & $10 \%$ \\
\hline & & Security & 2 & $5 \%$ \\
\hline & & & 40 & $100 \%$ \\
\hline \multirow{6}{*}{4} & \multirow{6}{*}{ Pendidikan } & SLTA & 9 & $23 \%$ \\
\hline & & Diploma & 20 & $50 \%$ \\
\hline & & S1 & 11 & $28 \%$ \\
\hline & & $\mathrm{S} 2$ & 0 & $0 \%$ \\
\hline & & S3 & 0 & $0 \%$ \\
\hline & & & 40 & $100 \%$ \\
\hline
\end{tabular}

Sumber: Data diolah, 2019

Berdasarkan Tabel 1 di atas maka dapat dijelaskan bahwa jumlah responden berdasarkan jenis kelamin yang terbanyak adalah laki-laki dengan jumlah 24 orang dengan persentase sebesar $60 \%$ sedangkan jumlah responden perempuan berjumlah 16 orang dengan persentase $40 \%$ dari total 40 responden. Dilihat dari lamanya responden bekerja, maka jumlah responden terbanyak berada pada rentan waktu lebih dari dua puluh tahun (> 20 tahun) yaitu sebanyak 28 orang dengan persentase $70 \%$ sedangkan untuk rentan waktu 1-10 tahun berjumlah 6 orang dengan persentase $15 \%$ dan rentan waktu 11-20 tahun berjumlah 6 orang dengan persentase $15 \%$.

Berdasarkan jabatan atau posisi responden dalam hotel Ayodya Resort Bali, maka dapat diketahui bahwa dari 40 orang responden pada penelitian ini, yang menduduki 
jabatan dalam departemen accounting yaitu 11 orang dengan persentase $28 \%$. Responden yang menduduki jabatan dalam departemen engineering, human resources, dan sales marketing sebanyak 4 orang dengan persentase masing-masing sebesar 10\%. Responden yang menduduki jabatan dalam departemen food \& beverage sebanyak 3 orang dengan persentase sebesar $8 \%$. Responden yang menduduki jabatan dalam departemen front office sebanyak 5 orang dengan persentase sebesar 13\%. Responden yang menduduki jabatan dalam departemen housekeeping sebanyak 7 orang dengan persentase sebesar 18\%. Dan responden yang menduduki jabatan dalam departemen security sebanyak 2 orang dengan persentase sebesar 5\%.

Berdasarkan dari tingkat pendidikan terakhir responden dalam hotel Ayodya Resort Bali, maka dapat dijelaskan bahwa responden dengan tingkat pendidikan terakhir yakni SLTA sebanyak 9 orang dengan persentase sebesar $23 \%$, untuk pendidikan terakhir diploma sebanyak 20 orang dengan persentase sebesar $50 \%$ dan untuk pendidikan terakhir S1 sebanyak 11 orang dengan persentase sebesar $28 \%$.

Statistik deskriptif memberikan informasi mengenai karakteristik variabelvariabel penelitian yang terdiri atas jumlah pengamatan, nilai minimum, nilai maksimum, nilai mean, dan standar deviasi. Tabel 2 menunjukkan hasil statistik deskriptif. 
Tabel 2.

Hasil StatistikDeskriptif

\begin{tabular}{llllll}
\hline Audit Operasional & 40 & 30,484 & 96,515 & 75,30987 & 16,907818 \\
Pengendalian Internal & 40 & 21,487 & 72,247 & 53,80215 & 13,959987 \\
Kinerja Karyawan & 40 & 23,380 & 60,946 & 48,59422 & 10,397321 \\
Valid N (listwise) & 40 & & & & \\
\hline
\end{tabular}

Sumber: Data diolah, 2019

Berdasarkan Tabel 2 di atastotal sampel yang digunakan adalah 40 responden. Variabel Audit Operasional memiliki nilai minimum 30,484, nilai maksimum 96,515 dan nilai rata-rata sebesar 75,31. Nilai standar deviasi variabel Audit Operasional sebesar 16,91. Hal ini berarti berdasarkan hasil statistik deskriptif terjadi perbedaan nilai Audit Operasional yang diteliti terhadap nilai rata-ratanya sebesar 16,91 dan nilai standar deviasi lebih rendah dibandingkan dengan nilai rata-rata, yang artinya sebaran data terkait Audit Operasional sudah merata.

Berdasarkan Tabel 2 di atas total sampel yang digunakan adalah 40 responden. Variabel Pengendalian Internal memiliki nilai minimum 21,487, nilai maksimum 72,247 dan nilai rata-rata sebesar 53,802. Nilai standar deviasi variabel Pengendalian Internal sebesar 13,96. Hal ini berarti berdasarkan hasil statistik deskriptif terjadi perbedaan nilai Pengendalian Internal terhadap nilai rata-ratanya sebesar 13,96 dan standar deviasi lebih rendah dibandingkan dengan nilai rata-rata, yang artinya sebaran data terkait Pengendalian Internal sudah merata.

Berdasarkan Tabel2 di atas total sampel yang digunakan adalah 40 responden. Variabel Kinerja Karyawan memiliki nilai minimum 23,38, nilai maksimum 60,946, dan nilai rata-rata sebesar 48,59. Nilai standar deviasi variabel Kinerja Karyawan10,4. Hal ini berarti berdasarkan hasil statistik deskriptif terjadi perbedaan 
nilai Kinerja Karyawan terhadap nilai rata-ratanya sebesar 10,4 dan standar deviasi lebih rendah dibandingkan dengan nilai rata-rata, yang artinya sebaran data terkait Kinerja Karyawan sudah merata.

Uji normalitas bertujuan untuk mengetahui apakah masing-masing variabel berdistribusi secara normal atau tidak. Pengujian normalitas data pada penelitian ini menggunakan uji Kolmogorov-Smirnov. Residual berdistribusi normal apabila nilai signifikansi Kolmogorov-Smirnov lebih besar dari 0,05. Hasil uji normalitas dapat dilihat pada Tabel 3 sebagai berikut.

\section{Tabel 3.} Uji Normalitas

\begin{tabular}{llr}
\hline & & \multicolumn{2}{c}{$\begin{array}{c}\text { Unstandardized } \\
\text { Residual }\end{array}$} \\
\hline$N$ & & 40 \\
Normal Parameters ${ }^{a, b}$ & Mean &, 00000000 \\
& Std. Deviation & 4,825176096 \\
Most Extreme Differences & Absolute &, 083 \\
& Positive &, 056 \\
& Negative &,- 083 \\
Kolmogorov-Smirnov $Z$ & &, 526 \\
Asymp. Sig. (2-tailed) & &, 945 \\
\hline Sumber: Data diolah, 2019 & &
\end{tabular}

Berdasarkan Tabel 3di atas dapat dilihat bahwa nilai Asymp.Sig. (2-tailed) sebesar 0,945 lebih besar dari $\alpha=0,05$, maka ini berarti bahwa residual dari model telah terdistribusi secara normal.

Uji multikoliniearitas bertujuan untuk menguji apakah dalam model regresi ditemukan adanya korelasi antar variabel bebas (independen). Model regresi yang baik seharusnya tidak terjadi korelasi diantara variabel independen. Untuk mendeteksi ada atau tidaknya multikolinieritas di dalam model regresi adalah dengan 
ISSN: 2302-8556

E-Jurnal Akuntansi

Vol.28.1.Juli (2019): 322-350

melihat nilai tolerance atau Variance Inflation Factor (VIF). Hasil uji multikolinearitas dapat dilihat pada Tabel 4sebagai berikut.

Tabel 4.

Hasil Uji Multikolinearitas

\begin{tabular}{llcr}
\hline & & \multicolumn{2}{c}{ Collinearity Statistics } \\
Model & & Tolerance & \\
\hline 1 & (Constant) & & \\
& Audit Operasional &, 477 & 2,097 \\
& Pengendalian Internal &, 477 & 2,097 \\
\hline
\end{tabular}

Sumber: Data diolah, 2019

Berdasarkan Tabel 4di atas menunjukkan bahwa variabel bebas memiliki nilai tolerance lebih dari 0,1 atau nilai VIF kurang dari 10, maka dapat dikatakan bahwa pada model regresi tidak terjadi gejala multikolinearitas.

Uji heteroskedastisitas bertujuan untuk menguji apakah dalam model regresi terjadi ketidaksamaan variance dari residual satu pengamatan ke pengamatan lainnya. Uji ini dapat dianalisis melalui uji glejser dengan melihat tingkat signifikansi, jika tingkat signifikansi berada di atas 0,05 maka model regresi ini bebas dari masalah. Hasil uji heteroskedastisitas dapat dilihat pada Tabel 5 sebagai berikut.

Tabel 5. Hasil Uji Heteroskedastisitas

\begin{tabular}{llr}
\hline \multicolumn{1}{c}{ Model } & Sig. \\
\hline 1 & (Constant) &, 156 \\
& Audit Operasional &, 193 \\
& Pengendalian Internal &, 200 \\
\hline
\end{tabular}

Sumber: Data diolah, 2019

Berdasarkan Tabel 5 menunjukkan bahwa nilai Sig. Dari masing-masing variabel tersebut diatas 0,05 sehingga seluruh variabel tersebut dapat dikatakan bebas dari heteroskedastisitas. 
Metode analisis dalam penelitian ini adalah metode analisis regresi linier berganda. Analisis regresi linier berganda digunakan untuk menguji pengaruh variabel audit operasional dan pengendalian internal terhadap variabel kinerja karyawan. Khaidah analisis regresi linier berganda mesti berdistribusi normal, dari analisis data yang dilakukan ternyata ada 3 sampel berdistribusi outliers. Hasil uji outliers dapat dilihat pada Tabel 6 sebagai berikut.

Tabel 6. Hasil Uji Outliers

\begin{tabular}{ccc}
\hline Record ID & Y & Cook's Distance \\
\hline 8 & 45.84 & 0.331 \\
9 & 25.21 & 0.170 \\
25 & 48.21 & 0.114 \\
\hline
\end{tabular}

Sumber: Data diolah, 2019

Model analisis dalam penelitian ini, yang menjadi variabel bebas adalah audit operasional $\left(\mathrm{X}_{1}\right)$ dan pengendalian internal $\left(\mathrm{X}_{2}\right)$, sedangkan untuk variabel terikatnya adalah kinerja karyawan (Y). analisis ini menggunakan bantuan SPSS Statistics 24.0 dalam pengolahan. Hasil analisis regresi linier berganda dapat dilihat pada Tabel 7 sebagai berikut.

\section{Tabel 7.}

Hasil Regresi Linier Berganda

\begin{tabular}{|c|c|c|c|c|}
\hline \multirow[t]{2}{*}{ Model } & \multicolumn{2}{|c|}{ Unstandardized Coefficients } & \multirow[t]{2}{*}{$\mathrm{t}$} & \multirow[t]{2}{*}{ Sig. } \\
\hline & $\mathrm{B}$ & Std. Error & & \\
\hline (Constant) & 6,775 & 3,691 & 1,835 & ,075 \\
\hline $\mathrm{X} 1$ & 0,382 & 0,068 & 5,622 & ,000 \\
\hline $\mathrm{X} 2$ & 0,243 & 0,082 & 2,949 & ,006 \\
\hline Adjusted R Square & ,773 & & & \\
\hline F Hitung & 67,399 & & & \\
\hline Signifikansi F & ,000 & & & \\
\hline
\end{tabular}


Berdasarkan Tabel 7 di atas diperoleh suatu persamaan regresi sebagai berikut:

$$
\mathrm{Y}=6,775+0,382 \mathrm{X}_{1}+0,243 \mathrm{X}_{2}+\varepsilon
$$

Pada pengujian ini dihitung besarnya koefisien determinasi $\left(\mathrm{R}^{2}\right)$ yang merupakan koefisien yang menunjukkan besarnya persentase pengaruh variabel independen terhadap variabel dependen. Besarnya nilai koefisien determinasi $\left(\mathrm{R}^{2}\right)$ ditunjukkan dengan nilai Adjusted $R$ Square. Nilai koefisien determinasi berada di antara kisaran nol sampai satu.

Berdasarkan Tabel 7 di atas dapat dilihat bahwanilai Adjusted $R$ Square pada model sebesar0,773. Nilai Adjusted $R$ Square pada model artinya variabel kinerja karyawan dapat dijelaskan oleh variabel audit operasional dan pengendalian internal,sebesar 77,3\%, sedangkan sisanya sebesar 22,7\% dijelaskan oleh variabel lain diluar model.

Uji F digunakan untuk melihat kelayakan model penelitian untuk dilanjutkan pengujian selanjutnya. Uji statistik $\mathrm{F}$ pada dasarnya menunjukkan apakah semua variabel independen atau bebas yang dimasukkan dalam model mempunyai pengaruh bersama-sama terhadap variabel dependen atau terikat. Bila nilai sig. dari $\mathrm{F} \leq \alpha$ sebesar (0,05), maka memenuhi syarat untuk uji kelayakan model.

Berdasarkan Tabel 7 dapat dilihat bahwa pada model memiliki nilai Signifikansi F sebesar 0,00 lebih kecil dari $\alpha=0,05$, menunjukkan model penelitian ini mampu memprediksi pengaruh variabel audit operasional dan pengendalian internal terhadap kinerja karyawan. 
Pengujian pada hipotesis pertama menunjukkan bahwa variabel audit operasional $\left(\mathrm{X}_{1}\right)$ berpengaruh positif pada kinerja karyawan. Berdasarkan Tabel 7 diatas diketahui bahwa nilai t audit operasional $\left(\mathrm{X}_{1}\right)$ sebesar 5,622 dengan signifikansi sebesar 0,000. Nilai signifikansi sebesar 0,000 lebih kecil dari $\alpha=0,05$ dengan nilai koefisien regresi sebesar 0,382 maka hipotesis pertama $\left(\mathrm{H}_{1}\right)$ diterima. Hasil ini menunjukkan bahwa audit operasional berpengaruh positif terhadap kinerja karyawan. Hasil penelitian mendukung hipotesis pertama $\mathrm{H}_{1}$ yakni audit operasional berpengaruh positif terhadap kinerja karyawan pada hotel Ayodya Resort Bali. Hasil penelitian ini mendukung penelitian sebelumnya yang dilakukan oleh Septianingrum (2017) yang menemukan audit manajemen berpengaruh postif terhadap kinerja karyawan. Audit manajemen yang dilakukan di Bank Panin Cabang Kendari telah dapat meningkatkan kinerja karyawan bank. Kinerja karyawan yang setiap periodenya dilakukan pemeriksaan untuk dapat dievaluasi kemudian diberikan solusi dan saran terhadap permasalahan yang ditemukan. Hasil penelitian yang dilakukan oleh Arvianita (2015) menemukan bahwa audit operasional berpengaruh positif dan signifikan terhadap efektivitas pelayan kesehatan di Rumah Sakit dengan diterapkannya audit operasional yang baik maka semakin meningkat pula efektivitas pelayanan kesehatan yang diberikan oleh Rumah Sakit. Hasil penelitian yang dilakukan oleh Rahmawati (2017) yang menemukan bahwa audit operasional berpengaruh secara signifikan terhadap kinerja karyawan rumah sakit dr $\mathrm{H}$ Marzoeki Bogor. Dengan demikian dapat dikatakan bahwa untuk menjaga kinerja karyawan perlu ada perbaikan secara terus 
menerus oleh Ayodya Resort Bali, dalam bidang pengawasan bagian operasional agar dapat melakukan kembali audit operasional di dalam hotel tersebut.

Pengujian pada hipotesis kedua menunjukkan bahwa variabel pengendalian internal $\left(\mathrm{X}_{2}\right)$ berpengaruh positif terhadap kinerja karyawan. Berdasarkan Tabel 7 diatas diketahui bahwa nilai $t$ pengendalian internal $\left(\mathrm{X}_{2}\right)$ sebesar 2,949 dengan signifikansi sebesar 0,006. Nilai signifikansi sebesar 0,006 lebih kecil dari $\alpha=$ 0,05dengan nilai koefisien regresi sebesar 0,243 maka hipotesis kedua $\left(\mathrm{H}_{2}\right)$ diterima. Hasil ini menunjukkan pengendalian internal berpengaruh positif terhadap kinerja karyawan. Hasil penelitian mendukung hipotesis kedua $\mathrm{H}_{2}$ yakni pengendalian internal berpengaruh positif terhadap kinerja karyawan pada hotel Ayodya Resort Bali. Hasil penelitian ini mendukung penelitian sebelumnya yang dilakukan oleh Arvianita (2015) yang menemukan pengendalian internal berpengaruh positif dan signifikan terhadap efektivitas kinerja karyawan rumah sakit. Semakin baik pengendalian internal yang dilakukan oleh sebuah instansi maka akan semakin meningkatkan efektivitas pelayan kesehatan pada Rumah sakit. Hasil penelitian yang dilakukan oleh Mirnasari dan Suardhika (2018) yang menemukan bahwa pengendalian internal memberikan pengaruh positif terhadap kinerja karyawan pada Bank Perkreditan Rakyat. Dengan adanya pengendalian internal dapat mengurangi kemungkinan kesalahan ataupun tindakan yang tidak sesuai dengan aturan yang dilakukan oleh karyawan. Hasil penelitian yang dilakukan oleh Agus et al., (2018) yang menemukan pengendalian internal berpengaruh positif terhadap kinerja Pemerintah Daerah. Dengan pelaksanaan pengendalian internal yang baik maka 
perusahaan akan memperoleh dampak positif, oleh karena itu di harapkan bagi Ayodya Resort Bali untuk menyediakan sarana yang memadai serta pelatihan khusus untuk karyawannya yang tentunya sangat mempengaruhi dalam pencapaian kinerja perusahaan yang baik.

Penelitian ini mendapatkan simpulan bahwa audit operasional dan pengendalian internal berpengaruh positif terhadap kinerja karyawan. Hal ini mendukung teori perilaku perencanaan (theory of planned behavior) yang menyatakan sikap, norma subjektif, dan persepsi kontrol keperilakuan akan menghasilkan keyakinan-keyakinan dari individu yang menimbulkan niat untuk berperilaku. Faktor organisasi yang mempengaruhi sikap dan perilaku karyawan dalam kinerjanya dengan diterapkannya audit operasional dan pengendalian internal menimbulkan keyakinan-keyakinan yang dimiliki seorang karyawan untuk menimbulkan niat yang tinggi dalam meningkatkan kinerjanya. Berdasarkan keyakinan tersebut akan mempengaruhi perilaku seseorang termasuk perilaku dalam bekerja.

Berdasarkan hasil penelitian ini, diharapkan dapat memberikan konstribusi positif, masukan dan bahan pertimbangan bagi semua pihak khususnya bagi hotel dalam pengambilan keputusan terkait dengan penerapan audit operasional dan pengendalian internal sehingga dapat meningkatkan kinerja karyawan secara efektif. Peningkatan kinerja pada karyawan secara efektif akan membawa dampak pada tercapainya tujuan Ayodya Resort Bali yang sesungguhnya.

Penelitian ini membawa dampak positif terhadap kinerja auditor internal dan pengawas internal yang ada di Ayodya Resort Bali. Auditor internal dan pengawas 
ISSN: 2302-8556

E-Jurnal Akuntansi

Vol.28.1.Juli (2019): 322-350

internal dalam melaksanakan tugasnya diharapkan dapat mempertimbangkan tentang pentingnya peningkatan kinerja karyawan untuk efektif dan efisiennya tujuan dari Ayodya Resort Bali.

\section{SIMPULAN}

Berdasarkan hasil analisis data dan pembahasan yang telah diuraikan diatas, maka dapat ditarik kesimpulan bahwa audit operasional berpengaruh positif terhadap kinerja karyawan pada hotel Ayodya Resort Bali. Dengan dilaksanakannya audit operasional berupa kegiatan pemeriksaan, pengevaluasian, penelaahan, dan pendeteksian, maka akan ditentukan hambatan dan ketidakefektivan yang kemudian akan dicari dan dipikirkan cara-cara untuk mengantisipasi dan menanggulangi hal-hal tersebut. Sehingga pada akhirnya keefektivan kinerja karyawan akan tercapai dan lebih lanjut lagi tujuan perusahaan dapat terlaksana dengan baik. Pengendalian internal berpengaruh positif terhadap kinerja karyawan pada hotel Ayodya Resort Bali. Adanya pengendalian internal dapat mengurangi kemungkinan kesalahan ataupun tindakan yang tidak sesuai dengan aturan yang dilakukan oleh karyawan.Dengan pengendalian internal yang baik maka kinerja karyawan dalam suatu perusahaan akan memperoleh dampak positif juga bagi kelangsungan perusahaannya.

Berdasarkan kesimpulan maka saran yang dapat disampaikan bagi Ayodya Resort Bali diharapkan dapat mengembangkan dan meningkatkan lagi penerapan audit operasional dalam hotel guna menemukan peluang dalam menekan pemborosan serta 
efisiensi biaya, merekomendasikan perbaikan kebijakan, prosedur, dan struktur organisasi hotel. Satuan pengawas internal dalam hotel diharapkan lebih meningkatkan usahanya untuk mengendalikan terjadinya risiko dalam kegiatan operasional hotel.

Peneliti selanjutnya disarankan untuk meneliti obyek lain yang berhubungan dengan penerapan audit operasional dan pengendalian internal pada hotel, karena dalam penelitian ini masih ada data outlier dan jawaban setiap pernyataan belum seluruhnya tepat.

\section{REFERENSI}

Agus, I. G., Putra, S., Pande, I. M., \& Putra, D. (2018). E-Jurnal Akuntansi Universitas Udayana Pengaruh Good Governance dan Sistem Pengendalian Intern Pemerintah Pada Kinerja Pemerintah Daerah Fakultas Ekonomi dan Bisnis Universitas Udayana ( Unud ), Bali , Indonesia email : agussudiarsana95@gmail.com / Telp : E-Jurnal Akuntansi Universitas Udayana, 25, 1720-1743.

Al-khaddash, H., Nawas, R. Al, \& Ramadan, A. (2013). Factors affecting the quality of Auditing: The Case of Jordanian Commercial Banks. International Journal of Business and Social Science, 4(11), 206-222. https://doi.org/10.1016/j.lindif.2008.05.003

Aprilia, N. R., Nazar, M. R., \& Zultilisna, D. (2017). Pengaruh Audit Operasional Dan Pengendalian Internal Terhadap Kinerja Perusahaan ( Studi Kasus Pada Hotel Inna Bali ) The Influence Of Operational Audit And Internal Control To Firm ( Case Study On Inna Bali Hotel ). E-Proceeding of Management, 4(2), 1572-1579.

Arvianita, R. R. (2015). Pengaruh Audit Operasional Dan Pengendalian Internal Terhadap Efektivitas Pelayanan Kesehatan Pada Rumah Sakit (Studi Kasus Pada Rumah Sakit Umum Queen Latifa Yogyakarta). Jurnal Pendidikan Akuntansi Fakultas Ekonomi Universitas Negeri Yogyakarta, 119(3), 859-867. 
Agoes, Sukrisno. (2014). Auditing Petunjuk Praktis Pemeriksaan Akuntan Oleh Akuntan Publik.Edisi ke 4. Buku 1. Jakarta: Salemba Empat.

Dewberry, C., \& Jackson, D. J. R. (2018). An application of the theory of planned behavior to student retention. Journal of Vocational Behavior, 107, 100-110. https://doi.org/10.1016/j.jvb.2018.03.005

Hidayati. (2013). Audit Manajemen Untuk Menilai Efektivitas Fungsi Sumber Daya Manusia (Studi Kasus Pada PT. Putra Barutama). Audit Manajemen Untuk Menilai Efektivitas Fungsi Sumber Daya Manusia (Studi Kasus Pada PT. Pura Barutama), 2(2).

Hight, S. K., Gajjar, T., \& Okumus, F. (2018). Managers from "Hell" in the hospitality industry: How do hospitality employees profile bad managers? International Journal of Hospitality Management, (February). https://doi.org/10.1016/j.ijhm.2018.06.018

Iqbal, A., \& Asrar-ul-Haq, M. (2018). Establishing relationship between TQM practices and employee performance: The mediating role of change readiness. International Journal of Production Economics, 203(June), 62-68. https://doi.org/10.1016/j.ijpe.2018.05.034

Iswara, D. (2015). Penerapan Audit Operasional Dalam Menilai Efisiensi Dan Efektivitas Fungsi Penjualan Pada CV. Anugerah Jaya Sidoarjo. Jurnal Akuntansi UBHARA, 83-93.

Ji, X. dong, Lu, W., \& Qu, W. (2018). Internal control risk and audit fees: Evidence from China. Journal of Contemporary Accounting and Economics, 14(3), 266287. https://doi.org/10.1016/j.jcae.2018.07.002

Kotabe, M., \& Kothari, T. (2016). Emerging market multinational companies' evolutionary paths to building a competitive advantage from emerging markets to developed countries. Journal of World Business, 51(5), 729-743. https://doi.org/10.1016/j.jwb.2016.07.010

Kramer, S., Maas, V. S., \& Rinsum, M. van. (2016). Relative performance information, rank ordering and employee performance: A research note. Management Accounting Research, 33, 16-24. https://doi.org/10.1016/j.mar.2016.03.004

Martini, P. \& R. (2017). Pengaruh Love Of Money, Organizational Citizenship Behavior Dan Kecerdasan Emosional Pada Kinerja Pegawai Universitas Udayana. E-Jurnal Akuntansi Universitas Udayana, 6.1, 303-328. 
McNulty, J. E., \& Akhigbe, A. (2017). What do a bank's legal expenses reveal about its internal controls and operational risk? Journal of Financial Stability, 30, 181-191. https://doi.org/10.1016/j.jfs.2016.10.001

Mirnasari, P. D., \& Suardhika, I. M. S. (2018). Pengaruh Penggunaan Teknologi Informasi , Efektivitas Sistem Informasi Akuntansi, dan Sistem Pengendalian Intern Terhadap Kinerja Karyawan. E-Jurnal Akuntansi Universitas Udayana, 23, 567-594. https://doi.org/https://doi.org/10.24843/EJA.2018.v23.i01.p22

Mulihartini, N. K. (2016). Tingkat Pendidikan Pada Efektivitas Fakultas Ekonomi dan Bisnis Universitas Udayana ( Unud ), Bali , Indonesia Pertumbuhan perekonomian suatu negara sangat erat kaitannya dengan peranan lembaga keuangan dimana lembaga keuangan berperan sebagai perantara b. E-Jurnal Akuntansi Universitas Udayana, 3, 1951-1977.

Noviani, K. S. (2018). Pengaruh Gaya Kepemimpinan Situasional, Motivasi dan Pelatihan Pada Kinerja Karyawan di Koperasi Pasar Srinadi Klungkung. EJurnal Akuntansi Universitas Udayana, 25, 2212-2241.

Perangin-angin, Z. (2017). E-Jurnal Akuntansi Universitas Udayana Pengaruh Sasaran Audit Manajemen Sumber Daya Manusia Terhadap Kinerja Karyawan Fakultas Ekonomi dan Bisnis Universitas Udayana ( Unud ), Bali , Indonesia Fakultas Ekonomi dan Bisnis Universitas Udayana ( Unud ), Bali. E-Jurnal Akuntansi Universitas Udayana, 21, 1993-2020.

Rahmawati, N. (2017). Peran Audit Operasional Dan Gaya Kepemimpinan Terhadap Kinerja Pelayanan (Studi Kasus Pada Instalasi Rawat Inap Non Psikiatri Di Rumah Sakit dr H Marzoeki Mahdi Bogor) (Vol. 91).

Sari, M. M. R. (2014). Persepsi Karyawan Atas Audit Manajemen Fakultas Ekonomi dan Bisnis Universitas Udayana ( Unud ), Bali , Indonesia. E-Jurnal Akuntansi Universitas Udayana, 3, 538-553.

Septianingrum, E. (2017). Pengaruh Audit Manajemen Terhadap Kinerja Karyawan Pada Pt Bank Panin Tbk Cabang Kendari. Jurnal Akuntansi (JAk), 37-49.

Shintia, C. I. P., \& Erawati, N. M. A. (2017). Pengaruh Kualitas SDM, Pemanfaatan Sistem Informasi, Pengendalian Intern dan Komitmen Organisasi Pada Kualitas Laporan Keuangan. E-Jurnal Akuntansi, 21, 1186-1205. https://doi.org/10.24843/eja.2017.v21.i02.p12 
Shu, W., Chen, Y., Lin, B., \& Chen, Y. (2018). Does corporate integrity improve the quality of internal control? China Journal of Accounting Research. https://doi.org/10.1016/j.cjar.2018.09.002

Tampang, E. B. (2011). Audit Manajemen Atas Fungsi Keuangan Audit Manajemen Atas Fungsi Keuangan Pada PT . Tirta Makna Bahagia Makassar.

Yadnyana, I. K. (2009). Pengaruh Kualitas Jasa Auditor Internal Terhadap Efektivitas Pengendalian Intern Pada Hotel Berbintang Empat Dan Lima Di Bali. Jurnal Ilmiah Akuntansi Dan Bisnis Universitas Udayana, 10, 315-320.

Yadnyana, I. K., \& Dewi, N. P. W. G. P. D. (2015). Evaluasi Efektivitas Pengendalian Internal: Studi Kasus Pada Pt Hutama Karya ( Persero ). Universitas Udayana, 2, 265-279. 